\title{
The Space Treaty: A Preliminary Evaluation
}

\author{
Ivan A. Vlasic*
}

W ITH THE SIGNING on January 27, 1967, of the Treaty on Principles Governing the Activities of States in the Exploration and Use of Outer Space, Including the Moon and Other Celestial Bodies, the world community acquired the basic charter for the future conquest and utilization of outer space. ${ }^{1}$ The adoption of this treaty can be regarded as terminating the first phase in the evolution of space law, a phase characterized more by emphasis upon the development of general principles than by the elaboration of more detailed rules and procedures. By any contemporary standards of treaty-making the agreement on the text of the Space Treaty was reached with uncommon speed; approximately six months elapsed between the initial submission by the United States and the Soviet Union of their competing draft proposals and the acceptance of the final text. The explanation for this speed can be found in the provisions of the treaty which consist to a very large extent of the principles agreed upon by the United Nations General Assembly in 1963 and included in Resolutions 1962 (Declaration of Legal Principles) ${ }^{2}$ and 1884. ${ }^{3}$ The desire of the United States and the Soviet Union to have a formal body of law ready before the first man lands on the moon, an event generally expected to occur not later than $1970,{ }^{4}$ contributed to the speed of the proceedings. Both countries "resisted the injection of

* B.C.I., 1949, University of Zagreb; LL.B., 1955, McGill University; LL.M., 1958, J.S.D., 1961, Yale University; Associate Professor, School of Law and Institute of Air and Space Law, McGill University.

1 The treaty was opened for signature simultaneously in Washington, London and Moscow, the capitals of the countries whose governments are designated by art. XIV, para. 3 , as depository governments. Representatives of 60 states signed the treaty in Washington on January 27, 1967. 56 DEp'T StaTe BuLx. 266 (1967). The treaty will enter into force when ratified by five nations, including the United States, United Kingdom and the Soviet Union. At the tine of writing the treaty had received unaninrous ratification by the United States Senate. N.Y. Times, April 26, 1967, at 1, col. 1. The treaty is reprinted in 55 DEP'T STATE BULI. 953-55 (1966).

2 G. A. Res. 1962, 18 U.N. GAOR Supp. 15, at 15, U.N. Doc. A/5656 (1963): "Declaration of Legal Principles Governing the Activities of States in the Exploration and Use of Outer Space." [Hereinafter cited as Declaration of Legal Principles.] For text see STAFF of Senate Comar. on Aeronatticat and Space Sciences, 89tr Cong., 2d Sess., Space Treaty Proposats by the Untred States and U.S.S.R. 27 (Comin. Print 1966). [Hereinafter cited as Space Treaty Proposats].

${ }^{3}$ G. A. Res. 1884, 18 U.N. GAOR Supp. 15, at 13, U.N. Doc. A/5571 (1963): "Question of General and Complete Disarmanient." For text see Space Treaty Proposals 32.

${ }^{4}$ See, e.g., NEwSWEEK, Jan. 16, 1967, at 73; President Johnson's Budget Message presented to Congress on Jan. 24, 1967, N.Y. Times, Jan. 25, 1967, at 20, col. 1. 
questions which, though important and logically related to the agreed principles, were not ripe for international negotiations." In this effort the proponents of the Space Treaty were amply aided by other participants in the negotiations, who advanced few proposals of their own and were prepared to modify or abandon them whenever they appeared controversial or contrary to the objectives of the United States and the Soviet Union. ${ }^{6}$ The result is a document which expresses general principles in diverse areas but breaks very little new ground. It leaves unsolved a number of problems which urgently need legal regulation.

\section{I \\ BACKGROUND OF THE TREATY}

Although the Soviet Union was the country which most persistently urged codification of the principles of space law enunciated in United Nations resolutions, particularly in the Declaration of Legal Principles of $1963,{ }^{7}$ it was the initiative of the United States that set negotiations on the Space Treaty in notion. The first tangible indication that the United States was considering such action came during the twentieth session of the Umited Nations. Speaking in the General Assembly on September 23, 1965, Ambassador Goldberg described the principles of the declaration as inadequate for the imminent expansion of space exploration to the moon and beyond. ${ }^{8}$ Accordingly, he suggested that the time was ripe for "the United Nations [to] begin work on a comprehensive treaty on the exploration of celestial bodies." Although the American representative did not accompany his suggestion with a draft proposal of a treaty or any specific recommendations, it is reasonable to assume that what he had in mind was not a mere restatement of the general provisions of the declaration but rather their elaboration into more detailed rules of behavior to guide future explorers of the celestial bodies. This interpretation is also consistent with the policy of the United States towards the status of the declaration; unlike the Soviet Union, the United States has always regarded the principles of that document

5 Goldberg, International Law in the United Nations, 56 Dep'T State Butx. 140, 142 (1967).

6 The modest scope of these proposals can be seen from U.N. Doc. A/AC.105/C.2/L.16, Annex II (1966), and U.N. Doc. A/6431, Annex III (1966). Typical was Australia's proposed amendment that the adoption of the treaty would not prejudice future negotiation of specific agreements.

7 See, e.g., statement by the Soviet Ambassador to the United Nations in U.N. Doc. A/AC.105/PV.37, at 51 (1965).

853 DEP'T STaTe BULx. 578, 585 (1965).

9 Id. The suggestion was later repeated by the U.S. representative in the Committee on the Peaceful Uses of Outer Space. U.N. Doc. A/AC.105/PV.37, at 62 (1965). 
as declarative of international law and hence as requiring no reiteration in a formal agreement. ${ }^{10}$ Nevertheless, neither the United States nor any other state put before the twentieth session of the General Assembly any specific proposals for a space treaty. Resolution 2130, adopted on December 21,1965 , clearly indicated the consensus of the Assembly that the Committee on the Peaceful Uses of Outer Space should in developing space law give the highest priority to the "preparation of draft international agreements on assistance to and return of astronauts and space vehicles and on liability for damage caused by objects launched into outer space."11 The task of incorporating into an international agreement the legal principles governing the activities of states in the exploration and use of space was to be given "consideration ... in the future as appropriate."12

Against this background, it must have come as a considerable surprise to the members of the United Nations when, on May 7, 1966, President Johnson proposed that the appropriate United Nations organ should begin without delay to prepare a "treaty laying down rules and procedures for the exploration of celestial bodies."13 Two days later, Ambassador Goldberg transmitted the text of the President's statement to the Chairman of the United Nations Committee on the Peaceful Uses of Outer Space and requested that he take the necessary steps "for an early convening of the Legal Subcommittee of the Committee on Outer Space."14 It should be noted that the President's proposal did not include

10 See the summary of Ambassador Stevenson's statement on the status of the Declaration of Legal Principles in 18 U.N. GAOR 159, UN. Doc. A/C.1/SR 1342 (1963). Particularly illustrative of the American position is the following observation made in the U.N. Committee on the Peaceful Uses of Outer Space by the U.S. representative, Mr. Nabrit: "A suggestion has been made that we should yield priority to the codification in treaty form of the Declaration of legal principles adopted by the General Assembly in 1963. As members will recall from Ambassador Stevenson's statement at that time, the United States attributes very important effects to that Declaration as it stands. We do not think the Declaration requires re-statement in any new form. This is not to say that work should not be done to embody in international agreements a statement of legal obligations which Member States would undertake in giving specific effect to individual principles set forth in the Declaration. For instance, we are anxious to see completed the agreements on liability and assistance and return, which have now been in preparation for eigliteen months. And, as Ambassador Goldberg proposed in his speech to the General Assembly on 23 September, we beheve that the Umited Nations slould undertake, in advance of manlandings on the moon, the drafting of international rules to govern the exploration of celestial bodies. ... We do not think it would enhance the prospects of success and accomplishment if an attempt were made to cover all these questions, and others too, in a single treaty or agreement." U.N. Doc. A/AC.105/PV.37, at 62 (1965).

11 G. A. Res. 2130, 20 U.N. GAOR Supp. 14, at 10, § 1, U.N. Doc. A/6212 (1965):

"International co-operation in the peaceful uses of outer space."

12 Id.

13 The text of the President's statement appcars in Space Treaty Proposals 1.

14 Id. at 2 . 
a draft-treaty but merely indicated the "essential elements" which the United States considered appropriate for immediate codification. These "essential elements" were entirely within the scope of previous U.N. space law resolutions. ${ }^{15}$

The response of the Soviet Union was not long in coming. On May 30, 1966, the permanent delegate of the U.S.S.R. to the United Nations, Ambassador Fedorenko, transmitted to the United Nations SecretaryGeneral a letter from the Soviet Foreign Minister A. A. Gromyko containing a request for "the inclusion in the agenda of the twenty-first session of the United Nations General Assembly, as a separate and important question, of the item 'Conclusion of an international agreement on legal principles governing the activities of States in the exploration and conquest of the moon and other celestial bodies. " $" 10$ The principles outlined by Gromyko as a desirable basis for the agreement were substantially identical with those suggested by President Johnson and, similarly, devoid of any novel ideas. The two proposals had another characteristic in common: Both were strictly limited to the moon and other celestial bodies.

The next phase in the process of preparing the Space Treaty began on June 16, 1966, when the United States and the Soviet Union submitted to the United Nations their separate draft treaties. ${ }^{17}$ A comparison of the two drafts reveals that both heavily relied in their substantive provisions upon the principles contained in the Declaration of Legal Principles and the General Assembly resolution 1884 which banned the stationing of weapons of mass destruction in outer space. In addition, both seem to have borrowed from the Antarctic Treaty ${ }^{18}$ the concept of inspection to ensure that no prohibited activities would take place on celestial bodies. In contrast to the mitial proposal made in the Gromyko letter, the Soviet draft-treaty was not limited to celestial bodies but also included provisions applicable to activities in outer space. The American draft proposal, true to President Johnson's statement of May 7th, was

15 They were as follows: (1) The moon and other celestial bodies should be free for exploration and use by all countries. No country should be permitted to advance a claim of sovereignty. (2) There should be frecdom of scientific investigation, and all countries should cooperate in scientific activities relating to celestial bodies. (3) Studies should be made to avoid harmful contamination. (4) Astronauts of one country should give any necessary help to astronauts of another country. (5) No country should be permitted to station weapons of mass destruction on a celestial body. Weapons tests and military maneuvers should be forbidden. Space Treaty Proposals 1.

16 For text of the Gromyko letter see Space Treaty Proposals 3-5.

17 For the United States draft-treaty see U.N. Doc. A/AC.105/32 (1966); for the Soviet draft-treaty see U.N. Doc. A/6352 (1966). Both proposals are reprinted in SpAcE Treaty Proposals 9-15.

18 Antarctic Treaty, Dec. 1, 1959, [1961] 1 U.S.T. 794, T.I.A.S. No. 4780. 
limited to celestial bodies. These were obviously minor differences, not likely to cause serious obstacles to agreement.

More serious were the differences between the accession clauses in the American and the Soviet drafts, which reflected familiar positions of both parties. The United States, attempting to prevent the accession of the regimes and entities which it does not recognize, proposed that the treaty be open for signature solely to states that are members of the United Nations, its specialized agencies, the International Court of Justice and others invited by the General Assembly; the Soviet Union, on the other hand, adopted the principle of universality. ${ }^{19}$ Provisions in the two drafts relating to the settlement of disputes were likewise at odds with one another. The American proposal giving the International Court of Justice a role in the resolution of controversies arising from the interpretation or application of the treaty ${ }^{20}$ had no equivalent in the Soviet draft. According to article $\mathrm{X}$ of the latter, such controversies were to be resolved exclusively through prompt consultation between the parties involved. ${ }^{21}$

The task of reconciling the differences between the Soviet and American draft proposals and of preparing a single unifonn text for submission to the 1966 session of the General Asembly was entrusted to the twentyeight-member Legal Subcommittee of the United Nations Committee on the Peaceful Uses of Outer Space. The subcommittee commenced its work in Geneva on July 12 and, by the time its first session ended on August 4 , had succeeded in reaching agreement on most of the articles for a final draft treaty. ${ }^{22}$ Negotiations on the remaining controversial articles were resumed in New York, where the subcommittee held meetings from September 12 to $16 .^{23}$ Complete agreement was achieved on December 8, 1966, as the twenty-first session of the General Assembly was drawing to a close; and, on December 19, the Assembly unanimously passed Resolution 2222 containing the text of the Space Treaty as an annex. $^{24}$

What was originally conceived of as an agreement limited to the regulation of interactions on celestial bodies had in the process of negotiations evolved into a document with a much wider scope. The treaty

19 Art. 12 of the United States draft; art. XI, para. 1 of the Soviet draft. In the final version of the treaty the principle of universality has been adopted. Art. XIV, para. 1.

20 Art. 2 of the United States draft.

21 The final version of the treaty contains no provisions relating to the settlenent of disputes.

- 22 The text of these articles appears in U.N. Doc. A/AC.105/C.2/L.16, Annex I (1966).

23 For the report of the Legal Subcommittee see U.N. Doc. A/6431, Annex III (1966).

24 U.N. Doc, A/RES/2222 (XXI): "Treaty Governing the Exploration and Use of Outer Space, including the Moon and Other Celestial Bodies," (1966) [hereinafter cited as Space Treaty]. 
incorporates a number of principles, rules and procedures which are applicable to activities throughout the environment of outer space. The inore important clauses of the treaty deal with the basic freedoms of outer space and celestial bodies, prevention of the arms race in outer space, and measures for securing safe and orderly conduct of space activities. Each of these groups of principles will be briefly examined.

\section{II}

\section{FREEDOMS OF OUTER SPACE}

Articles I and II of the treaty enunciate the fundamental freedoms of outer space. Article I declares that outer space, including the celestial bodies, sliall be free for exploration and use by all states on a basis of equality and that there shall be "free access to all areas of celestial bodies." No part of outer space or of any celestial body is "subject to national appropriation by claim of sovereignty, by means of use or occupation, or by any other means. ${ }^{125}$ Thus, the treaty excludes from application to the domain of space the traditional modalities of acquisition of unclaimed territory. None of these principles are new, however; they appear in substantially the same wording in the Declaration of Legal Principles adopted by the Assembly in $1963 .{ }^{26}$ Moreover, no state has ever challenged these policies. Since the very beginning of space exploration, states liave acted as if these fundamental freedoms were an integral part of international law. Indeed, after the unanimous adoption by the General Assembly of Resolution 1721, ${ }^{27}$ it became quite certain that no other solution would be acceptable to the community of states.

It is unfortunate that the treaty fails to elaborate upon these general principles, especially in view of the current race for the moon involving the two leading space powers which are also the principal rivals in the arena of world politics. The principles of nonappropriation and free access to all areas of celestial bodies as formulated in the treaty are too general to provide states with adequate guidance in solving certain practical problems which are likely to confront the lunar explorers. For example, given the probable scarcity of safe landing sites on the moon, will the early explorers be allowed to claim certain exclusive rights in sites which they liave first discovered and plysically occupied? Or, will they be per-

25 Space Treaty, art. II.

26 G. A. Res. 1962, 18 U.N. GAOR Supp. 15, at 15 (principles 2 \& 3), U.N. Doc. A/5656 (1963).

27 This resolution, entitled, "International Cooperation in the Peaceful Uses of Outer Space," and approved Dec. 20, 1961, was the first United Nations document to declare that "outer space and celestial bodies are free for exploration and use by all States in conformity with international law and are not subject to national appropriation." G. A. Res. 1721, 16 U.N. GAOR Supp. 17, at 6, U.N. Doc. A/5026 (1961). 
mitted to assert exclusive rights in certain useful materials located on such sites or in their vicinity? Are all other participants in lunar exploration free to use the same site if no other favorable landing spots exist in the area? Furthermore, the treaty is silent on the problem of allocation and management of valuable resources which may be found on celestial bodies, a problem which could cause serious controversy in the future and threaten the maintenance of world public order. ${ }^{28}$ The seriousness of these omissions is compounded by the lack of ineaningful exchange of information or coordination between the two principal rivals for space supremacy in regard to their programs for the conquest of the moon. It is not enough at this stage in the race for the moon merely to declare that all areas of outer space, including celestial bodies, are "free" and that no claims to sovereignty are allowed. The imminence of the manned exploration of the moon urgently requires a formulation of more detailed standards and procedures which will permit the disciplined implementation of this freedon and simultaneously safeguard the interests of all present and future participants in the exploration and use of celestial bodies.

\section{III}

PREVENTION OF THE ARMS RACE IN OUTER SPACE

Provisions of the treaty relating to the prevention of the arms race in outer space and on celestial bodies have been described by President Johnson as "the most important arms control development since the limited test ban treaty of 1963."29 In the absence of other disarmannent developments during the past three years, one can readily agree with this appraisal; it is somewhat difficult, however, to agree with the President of the twenty-first General Assembly session, Ambassador Pazliwak of Afghanistan, who saw in these provisions "a major step toward peace and lopefully to an end to the period of the cold war." ${ }^{30}$ The key provisions of the treaty found in article IV concerning military activities in outer space do not warrant such optimism. Paragraph 1 of this article reiterates almost verbatim the operative part of General Assembly Resolution 1884

28 The urgent need for a more specific regulation of the use of resources on celestial bodies has been recognized by a number of commentators. See, e.g., Goedhuis, Reflections on the Evolution of Space Law, 13 NETHERLANDS INT'L L. REv. 109, 149 (1966); Lachs, The International Law of Outer Space, 113 Recuerr Des Cours De L'ACADEMTE De Droit INTERnational 1, 54-55 (III, 1964). For some early proposals, see P. JessuP \& H. TaUbENFEID, CONTROLS For OUTER SPACE 276-82 (1959).

A semi-official French periodical has characterized the provisions of the Space Treaty relating to resources as "totally ambiguous." Le Traité de l'Espace, 6 LA RECHERCHE SPATIAIE 19, 20 (1967).

2955 DEP'T STATE BUtr. 952 (1966) (statement released on Dec. 8, 1966).

30 N.X. Times, Dec. 21, 1966, at 22, col. 1. 
of October 17, 1963, relating to "bombs in orbit." In contrast to this previous voluntary and informal undertaking, parties to the treaty are now under a legal obligation "not to place in orbit around the earth any objects carrying nuclear weapons or any other kinds of weapons of mass destruction, install such weapons on celestial bodies, or station such weapons in outer space in any other manner." Paragrapl 2 of article IV, focusing entirely on celestial bodies, forbids their use for the establishment of military bases, installations or fortifications, the testing of any kind of weapons, or the conducting of military maneuvers. However, it explicitly permits the employment of military personnel for scientific or for "any other peaceful purposes." The treaty nowhere explains what it means by "peaceful purposes," a term which appears with monotonous regularity in all United Nations space documents and is a frequent source of controversial interpretations. ${ }^{31}$ According to the view held by the United States, for example, all military activities in outer space are "peaceful" as long as they are not "aggressive." In2 Included among "peaceful" military uses of outer space under this interpretation is reconnaissance by satellites. The relevant provisions of the treaty do not make it plam whether observation conducted by the military from celestial bodies is permissible. ${ }^{33}$

To secure compliance with its arms control provisions, the treaty has adopted a concept of imspection which entitles the contracting parties to "free access to all areas of celestial bodies"34 and, in particular, to "all stations, installations, equipment and space vehicles on the moon and other celestial bodies. ${ }^{\prime 35}$ However, the Space Treaty, unlike the Antarctic Treaty, attaclies two conditions to the exercise of the right of inspection: It is to be exercised "on a basis of reciprocity" and then only after "reasonable advance notice" of a planned visit is given and "appropriate consultations" between the parties involved are held. ${ }^{36}$ The condition of "reciprocity" naturally raises a suspicion that the article affords the unwilling party an opportunity to nullify the right of inspection, a situation which cannot arise under the more straiglitforward provisions of the Antarctic Treaty. ${ }^{37}$ Despite Ambassador Goldberg's assertion that article

31 See generally C. Christox, The Internationat Law Of OUter Space 263-300 (1966).

32 Id. at 271.

${ }^{33}$ See Cooper, Some Crucial Questions About the Space Treaty, ATR Force \& SpACE Digest, March 1967, at 111.

34 Space Treaty, art. I, para. 2.

${ }^{35}$ Space Treaty, art. XII.

${ }^{36} I d$.

${ }^{37}$ Article VII, para. 2 of the Antarctic Treaty grants the inspection teams of the contracting parties "complete freedom of access at any time to any or all areas of Antarctica." Dec. 1, 1959, [1961], 1 U.S.T. 794, T.I.A.S. No. 4780. There is only one condition attached to this otherwise unlimited right: The names of the observers on the inspection 
XII does not "confer, or imply the existence of, any right or power to veto proposed visits to other countries' facilities on a celestial body, ${ }^{338}$ his own interpretation of the reciprocity clause is not entirely reassuring:

The meaning of the words "on the basis of reciprocity" in article XII is in fact the meaning which common sense would dictate-and which was fully accepted by all the members of the Legal Subcommittee in Geneva; namely, that representatives of a state party to the treaty conducting activities on celestial bodies will have a right of access to the stations, installations, equipment, and space vehicles of another state party on a celestial body, regardless of whether the second state has ever claimed, or has ever exercised, a right of access itself. The fact that the second state may not have asserted such a right, or may not have exercised it, in no way impairs the first state's right to access. However, if the first state has denied access to representatives of the second state, then the latter is not required, on the principle of reciprocity, to grant access to representatives of the first state. ${ }^{39}$

The requirement of advance notice of a projected visit and of subsequent consultations before inspection could be equally detrimental to the purposes of inspection by providing the offending state with the opportunity to conceal the forbidden equipment or temporarily terminate activities which are prohibited by the treaty. However, the unique conditions of the space environment and especially a concern for the safety both of astronauts and their facilities on celestial bodies seem to have made this stipulation desirable. ${ }^{40}$

It is worth emphasizing that with the exception of a clause banning the placing of weapons of mass destruction in orbit, the Space Treaty contains no other provisions designed to curb the arms race in the "void" of outer space. While it prohibits activities which have not yet been undertaken, such as the stationing of destructive weapons in orbit, and bars military installations on celestial bodies before the first astronaut has even landed on the celestial body nearest to the earth, the treaty in no way precludes states from continuing their current military space programs.

\section{IV}

SAFETY OF SPACE OPERATIONS

Next to the provisions relating to the ban on claims of sovereignty, freedom of access, and arms control, the most important clauses in the

teams must be communicated to all the other contracting states. See Simsarian, Inspection Experience Under the Antarctic Treaty and the International Atomic Energy Agency, 60 Arx. J. INT's L. 502, 503 (1966).

38 Statement made on Dec. 17, 1966, in Conmittee I of twenty-first General Assembly session. 56 DEP'T STATE BuLd. 78, 80 (1967).

${ }^{30} \mathrm{Id}$. (emphasis added).

$40 \mathrm{Id}$. at 81 . 
treaty are those which contaim prescriptions aimed at securing safe and orderly conduct of space activities. By and large these prescriptions have merely been transferred into the treaty, often verbatim, from the Declaration of Legal Principles. There are, however, certain innovations. Thus, in addition to the obligation to render astronauts in distress all possible assistance and provide for their prompt repatriation, ${ }^{41}$ parties to the treaty have undertaken to notify eacl other or the United Nations Secretary-General of "any phenomena they discover in outer space, including the moon and other celestial bodies, which could constitute a danger to the hife and health of astronauts." ${ }^{42}$ Even in the absence of a special international agreement on aid to astronauts in distress (still in the process of preparation in the Legal Subcommittee of the United Nations Committee on the Peaceful Uses of Outer Space), these provisions seem to afford adequate assurance that spacemen in need will receive assistance, regardless of their nationality.

Another novel, and in part safety-oriented, clause of the treaty obliges the contracting parties engaged in outer space activities to notify the Secretary-General and the international scientific community of the "nature, conduct, locations and results of sucl activities." ${ }^{\prime 3}$ At this time, reports on national space activities are furnished to the United Nations and to the concerned international scientific organizations, such as Committee on Space Research, ${ }^{44}$ on a voluntary basis; after the treaty enters into force, the contracting states will be under an obligation to provide such information. The fulfillment of this obligation is, however, subject to an important condition: Parties to the Treaty have agreed to supply the required data "to the greatest extent feasible and practicable," one would suspect that the reporting of certain military activities, potentially prejudicial to the safety of space exploration, may be characterized as "impracticable." This condition notwithstanding, the exchange of data required under the treaty should, in addition to promoting safety, result in a wide dissemination of new knowledge which will be especially beneficial to countries presently without space capabilities.

Common interest in safe and disciphined use of outer space is also expressed in article VI of the treaty, which makes states "internationally responsible" for space activities conducted by their nationals. Moreover, private entities are not allowed to engage in such activities without gov-

${ }^{41}$ Space Treaty, art. V, para. I \& 2. Paragraph 9 of the Declaration of Legal Principles has a similar provision.

42 Space Treaty, art. V, para. 3.

43 Space Treaty, art. XI. For some critical comments on this provision of the treaty, see Cooper, supra note 33, at 111 .

44 See note 47 infra; P. JESSUP \& H. TAUBENFELD, supra note 28, at 231-32.

${ }^{45}$ Space Treaty, art. XI. 
ernmental authorization; and the governments of the contracting states are under the obligation to exercise a continuing supervision over such private entities. The objective of these provisions is clearly to prevent reckless uses of outer space.

Of surpassing importance to the entire world community are those provisions of the treaty which contain measures for the protection of the earth-space environment from the risks of potentially harmful applications of space technology. ${ }^{46}$ The magnitude of such risks was recognized in the early days of space exploration, and since 1958 a special committee established under the auspices of the International Council of Scientific Unions has been studying and recommending measures designed to minimize the hazards to mankind inlerent in some space experiments. ${ }^{47}$ Article IX of the treaty, very largely patterned after the Declaration of Legal Principles, ${ }^{48}$ places an obligation upon the contracting parties to conduct their experiments in outer space so as to avoid "harmful contamination and also adverse changes in the environment of the Earth resulting from the introduction of extraterrestrial matter."49 It also provides, in general terms, for international consultation in regard to potentially harmful activities. Having established the principle of international consultation, however, the treaty neither prescribes the procedure for such consultation nor designates the agency to which states sliould turn for the authoritative evaluation of proposed experiments. ${ }^{50}$ To the allimportant question of the legal consequences of disagreement in the assessment of an experiment or activity, the treaty similarly provides no

46 Among the activities most likely to create such risks the following can at this time be identified: the use of nuclear energy in outer space, voyages to celestial bodies which may result in biological contamination of the earth and/or planets, and experiments with weather.

47 In 1958 the International Council of Scientific Unions (ICSU) established an ad hoc Committee on Contamination by Extraterrestrial Exploration (CETEX). To continue the functions of CETEX on a permanent basis, the Conimittee on Space Research (COSPAR) of the ICSU established in 1963 the Consultative Group on Potentially Harmful Effects of Space Experiments. This group consists of seven scientists who possess specialized knowledge of astronomy, radiation, physics, microbiology, atmospheric physics and chemistry, meteorite penetration and commumications. The work of CETEX is described in some detail in Johnson, Pollution and Contamination in Space, in LAW AND PoLITICS IN SPACE 37, 39-41 (M. Cohen ed. 1964). For an account of the activities of the consultative group see STAFF of Senate Conar. on Aeronatticat and Space Sciences, Internationad Cooperation and Organization for Outer Space, S. Doc. No. 56, 89th Cong., 1st Sess. 390-400 (1965).

48 Declaration of Legal Principles, para. 6.

40 This particular clause did not appear in the Declaration of Legal Principles. A similar provision can, however, be found in article 10 of the U.S. draft-proposal. U.N. Doc. A/AC.105/32 (1966).

50 COSPAR's Consultative Group is at present the only agency which is available to states for this purpose. See Staff of Senate Comam. on AEronaticat and Space ScIences, supra note 47, at 391 . See also C. JENKS, SPACE LAw 277 (1965). 
answer. These imperfections are compounded by the implied authority accorded each state to decide unilaterally which of its planned experiments or activities might cause deprivations to other states. Combined with the absence of a competent international control authority this could in practice render ineffectual the principle of consultation. ${ }^{51}$ In short, the provisions of the Space Treaty relating to control over potentially harmful space activities are too general and rudimentary to offer adequate protection to the world community against the hazards brought about by recent advances in technology. Admittedly, the regulation of these complex and delicate issues may be difficult while the fund of relevant technical criteria remains modest and the military implications of space activities continue high, but a prolonged delay in the introduction of appropriate preventive measures cannot be justified..$^{62}$ The alternative may be a repetition, possibly on a mucl larger scale, of the tragic consequences caused to our terrestrial environment by neglect in controlling air and water pollution. The most immediate need is for the establishment of an international organ with global responsibilities, preferably linked to the United Nations, to which all experiments and programs potentially harmful to the earth-space environment would have to be reported in advance, and whose determination in each case would be final. ${ }^{53}$ The same organ should, of course, be authorized to order the cessation of programs already in progress whose harmful effects are discovered only after they have been initiated.

\section{CONCLUSTON}

No evaluation of the Space Treaty, lowever brief and preliminary, can afford to overlook that document's potential impact upon the future role of the General Assembly in the regulation of outer space activities. One of the most remarkable features in the evolution of space law during the past decade has been the emergence of the General Assembly as the principal world community organ for setting standards of conduct in the new environment. Soon after the advent of the space age it became apparent that for the overwhelming majority of states the United Nations was the proper forum to be entrusted with the formulation of the funda-

51 For a critique of the identical deficiencies found in the Declaration of Legal Principles see Lachs, supra note 28, at 73. See also C. JENKs, supra note 50, at 278.

62 For an excellent and comprehensive proposal see David Davies Memorial Institute, Draft Rules Concerning Changes in the Environment of the Earth, in JENks, supra note 50 , at $430-39$.

53 COSPAR's Consultative Group, despite its semi-official link with the United Nations, lias at the moment neither the authority nor the resources to play this role. It could, however, be used as a nucleus for the new organization. Accord, Schick, A Subjective Approach to the Work of the United Nations Committee on the Peaceful Uses of Outer Space, 5 Diritto Aereo 204, 212 (1966). 
mental rules of behavior in outer space interactions. ${ }^{54}$ Although the General Assembly is not empowered by the United Nations Charter to legislate except on matters of internal organization, it was not regarded as barred from enunciating certain basic principles of space law and from expecting states to act accordingly. Through such unique intervention the General Assembly inay be said to have laid the foundations for a disciphned and non-violent use of outer space. The high mark of these regulatory activities of the Assembly was undoubtedly the Declaration of Legal Principles. While appraisals of this document cover a wide spectrum of opinion, ${ }^{65}$ the prevailing view prior to the negotiations of the Space Treaty was that the declaration states obligations not unlike those under a formal agreement. Whatever may be the ultimate characterization of the declaration, its effect in practice did not materially differ from the effects which one would expect to result from a treaty: No state has either protested or, as far as is known, acted in violation of its principles.

This immensely useful quasi-legislative role of the General Assembly in the field of space law may lave been undermined, and the authority of its future law-oriented space resolutions diminished, by the conclusion of the Space Treaty. If the text of the treaty incorporated provisions elaborating upon the principles contained in the declaration, or covered important new ground, as was reasonably expected following the original initiative of Ambassador Goldberg, ${ }^{56}$ such anxiety would not arise. But the treaty only modestly broadens the horizons of the existing space law and seldom departs front the principles already widely regarded as inposing firm obligations upon states. Appraised in this light, the adoption of the treaty will surely strengthen the view, until recently limited to a few states and even fewer publicists, that the outer space resolutions of the General Assembly are merely non-binding expressions of intent, regardless of their subject matter and universal endorsement. ${ }^{57}$ It would be most unfortunate for the cause of public order in outer space if the future shows that states have by their recent action on the Space Treaty permanently impaired the decision-making usefuhress of the United $\mathrm{Na}$ tions General Assembly.

54 Documentation is offered in M. McDodgal, H. Lasswelc \& I. VLasic, Law AND Public ORder IN Space 204-27 (1963). See also Christor, supra note 31, at 183-205.

55 See, e.g., C. JENkS, Space Law 186 (1965); Cheng, United Nations Resolutions on Outer Space: 'Instant' Intemational Customary Law?, 5 INDIAN J. INT'L L. 23 (1965); Goedhuis, supra note 28, at 111; Hlestov, The Elaboration of Space Law Norms, SovestskoE Gosudarstvo I Pravo, Aug. 1964, at 75; Lachs, supra note 28, at 96-99.

56 See text accompanying note 9 supra.

57 For a collection of relevant statements see Goedhuis, supra note 28, at 112-22; Cheng, supra note 55. An excellent brief appraisal of the law-creating contribution of the General Assembly to world public order is offered in Falk, On the Quasi-Legislative Competence of the General Assembly, 60 Axr. J. INr'x L. 782 (1966). 


\section{California Law Review}

\begin{tabular}{lll}
\hline \hline VoL. 55 & MAY 1967 & No. 2 \\
\hline \hline
\end{tabular}

BOARD OF EDITORS

\begin{tabular}{|c|c|}
\hline $\begin{array}{l}\text { CARI J. SENEKER II } \\
\text { Editor-in-Chief }\end{array}$ & $\begin{array}{c}\text { CEARIES H. WIISON, JR. } \\
\text { Managing Editor }\end{array}$ \\
\hline $\begin{array}{l}\text { BARBARA BRUDNo RINTALA } \\
\text { Article Editor }\end{array}$ & $\begin{array}{l}\text { GEORGE A. CUManTNo, JR. } \\
\text { Note \& Comment Editor }\end{array}$ \\
\hline $\begin{array}{l}\text { DAVDD ALAN LETPZIGER } \\
\text { Article Editor }\end{array}$ & $\begin{array}{l}\text { KENNETH A. GoLDMAAN } \\
\text { Note \& Comment Editor }\end{array}$ \\
\hline $\begin{array}{l}\text { Davm B. FroHNMaAER } \\
\text { Research and Chief } \\
\text { Note \& Comment Editor }\end{array}$ & $\begin{array}{l}\text { ALEXANDER M. HEEMEYER } \\
\text { Note \& Comment Editor }\end{array}$ \\
\hline $\begin{array}{l}\text { EDMOND R. MANWELI } \\
\text { Book Review Editor }\end{array}$ & $\begin{array}{c}\text { ROBERT CARL HERR } \\
\text { Note \& Comment Editor }\end{array}$ \\
\hline $\begin{array}{l}\text { MYRON G. SUGARMAN } \\
\text { Business Editor }\end{array}$ & $\begin{array}{c}\text { SaNDRa TERzIAN } \\
\text { Note \& Comment Editor }\end{array}$ \\
\hline $\begin{array}{l}\text { WIIIIAM: T. RINTALA } \\
\text { Executive Editor }\end{array}$ & $\begin{array}{c}\text { Tracy A. WeSTEN } \\
\text { Note \& Comment Editor }\end{array}$ \\
\hline $\begin{array}{c}\text { JERRY J. BERMaN } \\
\text { Note \& Comment Editor }\end{array}$ & $\begin{array}{l}\text { STARLEY H. WULTIAMS } \\
\text { Note \& Comment Editor }\end{array}$ \\
\hline
\end{tabular}

KEXIY C. WOOSTER

Note \& Comment Editor

Robert ALAN BLUM

ALAN G. CarLTON

DANIEL S. FROST

BRUCE BABCOCK, JR. JEFFREY FRED BECK JOSEPH C. BELX John Jackson BentleEY III PaUd B. Bergaman WIIITAMI S. BETEAND STEPHEN J. BISGEIER LAWRENCE L. CURTICE TtMothy Dreyfus Michaed C. Ferguson Steven H. Goldfarb
Associate Editors MARTIN E. Harband DaILas Holares

\section{Candidates}

AtTSON M. GREY EMLEN HALL GUGGENHTME Robert ERNest GyEMAaNT RICHARD V. HATI AIAN E. HARRIS Douglas A. HaYder JOHN E. HUERTA WIILIAAM L. J JAEGER Biadne Covington Jantis Donatus Januta Michaer Justin Myers

RICHARD C. HuNT STEven M. KIPPERMAN SeIvyn Semel

George Richard Poether Jomn F. Prttchard MARK REUTIINGER Dodglas M. Schwab DANIEL U. SMatTE JefFrey Davm Sobet JANet Friedman Stansby Kristtine Mary Strachan Wutraar Roger Stretow WIIIIAMI T. VUROWICH Peter K. Westen

MarJorte DevereuX Administrative Assistant 